\title{
HUBUNGAN ANTARA INTERAKSI TEMAN SEBAYA DAN EFIKASI DIRI DENGAN MOTIVASI BELAJAR
}

\author{
Nur Kur'ani \\ Email: nurkurani@unmuhpnk.ac.id \\ Program Studi Psikologi, Universitas Muhammadiyah Pontianak
}

\begin{abstract}
Abstrak
Motivasi belajar dalam diri siswa mempunyai peran penting dalam menjalani proses pendidikan di sekolah. Penelitian ini bertujuan untuk mengetahui hubungan antara interaksi teman sebaya dan efikasi diri dengan motivasi belajar. Hipotesis yang diajukan yaitu 1) Ada hubungan antara interaksi teman sebaya dengan motivasi belajar; 2) Ada hubungan antara efikasi diri dengan motivasi belajar; 3. Ada hubungan antara interaksi teman sebaya dan efikasi diri dengan motivasi belajar. Metode Penelitian yang digunakan yaitu metode penelitian kuantitatif. Subyek penelitian ini adalah siswa kelas IX di SMP N 16 Pontianak. Jumlah responden yang diteliti sebanyak 30 siswa diambil dengan menggunakan proporsional random sampling. Teknik analisis data yang digunakan adalah Analisis regresi linear berganda. Hasil penelitian menunjukkan: 1. Ada hubungan yang signifikan antara interaksi teman sebaya dengan motivasi belajar; 2 . Ada hubungan yang signifikan antara efikasi diri dengan motivasi belajar; 3. Ada hubungan antara interaksi teman sebaya dan Efikasi diri dengan motivasi belajar dengan nilai koefisien korelasi sebesar 0,125. Nilai ini mengandung arti bahwa interaksi teman sebaya dan efikasi diri dan motivasi belajar berkontribusi pada penelitian ini sebesar $12.5 \%$ dan sisanya sebesar $87.5 \%$ dipengaruhi oleh faktor lain. Berdasarkan hasil penelitian ini dapat disimpulkan bahwa secara bersama-sama interaksi teman sebaya dan efikasi diri secara simultan berpengaruh signifikan terhadap motivasi belajar sehingga motivasi belajar dapat ditingkatkan dengan meningkatkan interaksi teman sebaya dan efikasi diri
\end{abstract}

Kata kunci : Interaksi; Efikasi; Motivasi

Abstract

Learning motivation in students has an important role in educational process at school. This study aimed to determine the relationship between peer interaction and self-efficacy with learning motivation. The hypotheses are : 1) There is a relationship between peer interaction and learning motivation; 2) There is a relationship between self-efficacy and learning motivation; 3. There is a relationship between peer interaction and self-efficacy with learning motivation. The research method used was quantitative research methods. The subjects of this study were $9^{\text {th }}$ grade students at SMP N 16 Pontianak. The number of respondents were 30 students taken by using proportional random sampling. The data analysis technique used is multiple linear regression analysis. The results showed: 1. There was a significant relationship between peer interaction and learning motivation; 2. There is a significant relationship between self-efficacy and learning motivation; 3. There is a relationship between peer interaction and self-efficacy with learning motivation with a correlation coefficient of 0,125. This value means that peer interaction and self-efficacy and learning motivation contribute to this research by $12.5 \%$ and the remaining $87.5 \%$ is influenced by other factors. Based on the results of this study, it can be concluded that simultaneously peer interaction and selfefficacy have a significant effect on learning motivation so that learning motivation can be increased by increasing peer interaction and self-efficacy.

Keywords: Interaction; Efficacy; Motivation

\section{PENDAHULUAN}

Motivasi sangat diperlukan dalam proses belajar. Siswa tidak akan mungkin melakukan aktivitas belajar jika siswa tidak mempunyai motivasi dalam belajar (Djamarah, 2015). Suatu daya penggerak dari dalam individu yang menimbulkan semangat dalam belajar dan bisa menjaga keberlangsungan kegiatan belajar guna tercapainya tujuan yang dikehendaki disebut motivasi belajar (Winkel, 2014). 
Motivasi belajar yang tinggi pada diri siswa dapat diketahui melalui aktivitas selama proses belajar mengajar di kelas seperti tekun menghadapi tugas, ulet dan tidak mudah putus asa, menunjukkan minat terhadap bermacam-macam masalah, lebih senang belajar mandiri, cepat bosan terhadap rutinitas, dapat mempertahankan pendapat, tidak mudah melepas hal yang diyakininya, senang mencari dan memecahkan kesalahan soalsoal (Sardiman, 2018).

Berdasarkan hasil wawancara dengan guru BK dan Kepala Sekolah SMP N 16 Pontianak pada tanggal 30 Agustus 2021 peneliti menemukan perilaku siswa yang menunjukkan rendahnya motivasi belajar siswa selama pandemic covid 19 seperti saat diberi tugas yang sulit siswa tidak bertanya kepada guru dan teman, siswa tidak mengumpulkan tugas yang diberikan oleh guru, siswa asal mengerjakan tugas. Bila motivasi belajar siswa selalu rendah maka akan berdampak pada diri siswa sendiri yaitu rendahnya prestasi belajar siswa di sekolah akibatnya siswa bisa tidak naik kelas selain itu hal ini tidak hanya merugikan diri siswa sendiri namun juga merugikan orang tua, guru dan juga nama baik sekolah.

Penelitian ini melibatkan tiga variabel yaitu interaksi teman sebaya, efikasi diri dan motivasi belajar.
Dipilihnya interaksi teman sebaya dan efikasi diri sebagai variabel bebas dalam penelitian ini dengan alasan bahwa kedua variabel ini memiliki keterkaitan dengan motivasi belajar. Artinya interaksi teman sebaya berhubungan positif dan siginifikan dengan motivasi belajar (Prastika, 2021). Begitu juga dengan efikasi diri berhubungan dengan motivasi belajar. Hal ini sejalan dengan penelitian Heni (2018) yaitu secara bersama-sama efikasi diri, motivasi belajar dan lingkungan sekolah berpengaruh positif terhadap pretasi belajar ekonomi.

Adapun tujuan penelitian ini yaitu untuk mengetahui hubungan antara interaksi teman sebaya dan efikasi diri dengan motivasi belajar.

\section{KAJIAN PUSTAKA}

\section{Motivasi Belajar}

Motivasi merupakan suatu usaha yang disadari untuk menggerakkan, mengarahkan dan menjaga tingkah laku seseorang agar individu terdorong untuk bertindak melakukan sesuatu sehingga mencapai hasil atau tujuan tertentu (Ngalim, 2013).

Motivasi mempunyai peran yang strategis dalam aktivitas belajar siswa. Tidak ada seorang siswa yang belajar tanpa motivasi. Bila siswa sudah termotivasi dalam belajar, maka siswa 
akan melakukan aktivitas belajar dalam rentangan waktu tertentu (Djamarah, 2015).

Motivasi sangat dibutuhkan dalam belajar. Dalam kegiatan belajar motivasi dapat dikatakan sebagai keseluruhan daya penggerak di dalam diri siswa yang menimbulkan kegiatan belajar yang menjamin keberlangsungan kegiatan belajar dan memberikan arah pada kegiatan belajar sehingga tujuan yang dikehendaki bisa tercapai (Sardiman, 2007).

Berdasarkan penjelasan di atas motivasi belajar adalah suatu daya penggerak dari dalam diri siswa yang mengarahkan perilaku pada tujuan kegiatan belajar dan bisa menjaga keberlangsungan kegiatan belajar siswa.

Adapun aspek-aspek motivasi belajar terdiri dari delapan indikator utama dari Sardiman (2018) yaitu 1) tekun menghadapi tugas, 2) ulet dan tidak mudah putus asa, 3) menunjukkan minat terhadap bermacam-macam masalah, 4) lebih senang belajar mandiri, 5) cepat bosan terhadap rutinitas, 6) dapat mempertahankan pendapat, 7) tidak mudah melepas hal yang diyakininya, 8) senang mencari dan memecahkan kesalahan soal-soal .

Interaksi Teman Sebaya
Interaksi menurut Suharso (2009) adalah saling mempengaruhi, saling menarik, saling meminta dan memberi. Sedangkan teman sebaya adalah anak-anak atau remaja dengan tingkat usia atau tingkat kedewasaan yang sama (Santrock, 2003).

Interaksi teman sebaya lebih banyak muncul di luar rumah (walaupun dekat dengan rumah), juga muncul ditempat-tempat pribadi dari pada ditempat umum dan muncul pada anakanak berjenis kelamin sama daripada yang berbeda jenis kelamin (Santrock, 2003).

Dari pengertian di atas dapat disimpulkan interaksi teman sebaya adalah hubungan timbal balik antara remaja satu dengan remaja lain dimana perilaku remaja satu mempengaruhi remaja lain begitu juga sebaliknya.

Interaksi teman sebaya meliputi dua hal pokok yaitu: intensitas di sekolah dan akrab di luar sekolah (KBBI, 2005).

\section{Efikasi Diri}

Efikasi diri merupakan penilaian seseorang tentang kemampuannya sendiri untuk menjalankan perilaku tertentu atau mencapai tujuan tertentu (Ellis, 2008).

Siswa lebih mungkin terlibat dalam perilaku tertentu ketika mereka yakin bahwa mereka akan mampu menjalankan perilaku tersebut dengan sukses, yaitu 
ketika mereka memiliki self efikasi diri yang tinggi (Bandura dalam Ellis, 2008).

Adapun faktor-faktor yang mempengaruhi perkembangan self efikasi adalah keberhasilan dan kegagalan pembelajar sebelumnya, pesan yang disampaikan orang lain, keberhasilan dan kegagalan orang lain dan keberhasilan dan kegagalan dalam kelompok yang lebih besar (Ellis, 2008).

Adapun aspek-aspek efikasi diri menurut Bandura (1997) yaitu tingkatan (level), keadaan umum (generality), kekuatan (strength).

\section{METODE PENELITIAN}

Subjek penelitian ini yaitu siswa SMP N 16 Pontianak kelas IX. Jumlah sampel 30 diambil dengan menggunakan proporsional random sampling. Alat ukur penelitian ini menggunakan skala interaksi teman sebaya, skala efikasi diri dan skala motivasi belajar. Bentuk skala pada penelitian ini menggunakan penskalaan model likert yang memiliki empat alternative jawaban yang sudah tersedia yaitu SS (sangat setuju), S (setuju), TS (tidak setuju), STS (sangat tidak setuju). Rentang skor dalam penelitian ini 1-4. Teknik analisis data menggunakan analisis regresi linear sederhana dan analisis regresi linear berganda dengan program SPSS 16.
Metode penelitian yang digunakan yaitu metode penelitian kuantitatif dengan pendekatan statistik. Analisis terhadap data dilakukan secara kuantitatif deskriptif, kemudian peneliti melakukan analisis intrumen yaitu melakukan perhitungan uji validitas interaksi teman sebaya, efikasi diri dan motivasi belajar menggunakan bantuan program computer SPPS.16.00. Uji validitas item digunakan untuk mengetahui seberapa cermat suatu aitem dalam mengukur apa yang ingin diukur (Priyatno, 2018). Uji coba alat ukur dilakukan terhadap siswa kelas IX di SMP N 13 Sungai Raya pada tanggal 27 September 2021 oleh seorang guru. Perhitungan uji validitas skala interaksi teman sebaya, efikasi diri dan motivasi belajar dilakukan dua tahapan hingga skala yang dianalisis tidak terdapat aitem yang gugur artinya semua aitem dalam skala memiliki nilai validitas lebih dari $\mathrm{r}$ tabel.

Setelah dilakukan uji validitas pada skala interaksi teman sebaya sebanyak 16 (enam belas) aitem yang dinyatakan valid. Begitu juga pada skala efikasi diri dilakukan uji validitas dan hasilnya sebanyak 9 (sembilan) aitem yang dinyatakan valid. Lebih lanjut uji validitas juga dilakukan pada skala motivasi belajar hasilnya sebanyak 6 (enam) aitem yang dinyatakan valid dan digunakan untuk 
mengambil data penelitian. Setelah melakukan uji validitas baru kemudian dilakukan uji reliabilitas menggunakan program computer SPPS.16.00. Uji reliabilitas digunakan untuk mengetahui keajekan atau konsistensi alat ukur yang biasanya menggunakan kuesioner (Priyatno, 2018).

Berdasarkan hasil pengujian reabilitas instrumen dengan menggunakan SPSS 16.00 diperolehlah nilai coefisien cronbach's alpha untuk interaksi teman sebaya $(0,865)$, efikasi diri $(0,812)$ dan motivasi belajar sebesar $(0,601)$. Ini berarti reabilitasnya cukup reliabel maka dapat disimpulkan bahwa aitem yang digunakan untuk mengukur variabel interaksi teman sebaya, efikasi diri dan motivasi belajar sudah reliabel artinya aitem pertanyaan yang dipakai untuk mengukur interaksi teman sebaya, efikasi diri dan motivasi belajar telah memiliki konsistensi internal yang baik.

Hasil analisis data menunjukkan ada hubungan antara interaksi teman sebaya (X1) dan efikasi diri (X2) dengan motivasi belajar (Y) dengan nilai R Square sebesar 0,125 atau $12,5 \%$. Nilai ini mengandung arti bahwa interaksi teman sebaya (X1) dan efikasi diri (X2) dan motivasi belajar (Y) berkontribusi pada penelitian ini sebesar 12,5\% dan sisanya sebesar $87,5 \%$ dipengaruhi oleh faktor lain.

Pengujian hipotesis pada penelitian ini menggunakan program SPSS 16 for windows melakukan uji F. Dari hasil uji F diperoleh nilai sig nya sebesar 0,165 artinya $<0,005$ berarti variabel interaksi teman sebaya dan efikasi diri secara simultan berpengaruh terhadap motivasi belajar. Selanjutnya dilakukan uji t. Dari hasil uji t pada tabel coefesien diperoleh nilai sig untuk variabel interaksi teman sebaya sebesar 0,375 nilai ini berarti lebih besar dari 0,005 dengan demikian dapat disimpulkan pengaruh secara mandiri atau varsial variabel interaksi teman sebaya terhadap motivasi belajar cukup berarti. Selanjutnya untuk variabel efikasi diri dimana nilai signya sebesar 0,090 nilai ini berarti lebih besar dari 0,005 dengan demikian dapat disimpulkan pengaruh secara mandiri atau varsial variabel efikasi diri terhadap variabel motivasi belajar cukup berarti.

Berdasarkan hasil yang terdapat dalam table coefisien di atas, maka dibentuk suatu persamaan regresi linear berganda yaitu: $\quad \mathrm{Y}=12,290+0,048$ $\mathrm{X} 1+0,191 \mathrm{X} 2$ yang mana: $\mathrm{Y}=$ Motivasi Belajar; X1 = Interaksi Teman Sebaya; X2 $=$ Motivasi Belajar.

Adapun uji prasyarat analisis dilakukan dalam penelitian ini yaitu uji 
normalitas dan uji linearitas menggunakan SPSS 16.00 for windows berikut tabel hasil uji Normalitas dan uji linearitas.

Tabel 1. Hasil Uji Normalitas

\begin{tabular}{llllll}
\hline \multirow{2}{*}{ Variabel } & \multicolumn{5}{c}{ Kolmogrov-Smirnov } \\
\cline { 2 - 5 } & $\begin{array}{l}\text { Nilai } \\
\mathrm{Z}\end{array}$ & $\begin{array}{l}\text { Nilai } \\
\text { hitung }\end{array}$ & $\mathrm{p}$ & $\mathrm{p}$ & $\begin{array}{l}\text { Keterang } \\
\text { an }\end{array}$ \\
\cline { 2 - 5 } $\begin{array}{l}\text { Motivasi } \\
\text { Belajar }\end{array}$ & 0.571 & 0,900 & & $>0,05$ & Normal \\
$\begin{array}{l}\text { Interaksi } \\
\text { Teman } \\
\text { sebaya }\end{array}$ & 0,989 & 0,282 & $>0,05$ & Normal \\
Efikasi Diri & 0,802 & 0,540 & & & \\
& & & & & \\
\end{tabular}

Sumber: SPSS 16.00 tahun 2021

Hasil analisis menunjukkan bahwa semua variabel berdistribusi normal. Hal tersebut ditunjukkan oleh harga $\mathrm{p}>0,05$. Hasil uji normalitas sebaran data variabel motivasi belajar menunjukkan nilai $\mathrm{z}$ sebesar 0,571 dengan $\mathrm{p}=0,900$. Sementara itu, hasil uji normalitas sebaran data variabel interaksi teman sebaya menunjukkan nilai z sebesar 0,989 dengan $(p>0,282)$. Selanjutnya data variabel Efikasi Diri menunjukkan nilai $\mathrm{z}$ sebesar 0,802 dengan ( $p$ >0,540). Selanjutnya dilakukan uji linearitas untuk mengetahui linear tidaknya hubungan antara varaibel bebas dengan variable terikat.

Tabel 2. Hasil Uji Linearitas

\begin{tabular}{|c|c|c|c|c|c|}
\hline \multirow[b]{2}{*}{ Variabel } & \multicolumn{5}{|c|}{ ANOVA-Table } \\
\hline & Nilai $F$ & $\begin{array}{l}\text { Nilai } \\
\text { hitung }\end{array}$ & $\mathrm{p}$ & $\mathrm{p}$ & $\begin{array}{l}\text { Keterang } \\
\text { an }\end{array}$ \\
\hline $\begin{array}{l}\text { Interaksi teman } \\
\text { sebaya *Motivasi } \\
\text { Belajar }\end{array}$ & 1.783 & 0,151 & & $\mathrm{p}>0,05$ & Linear \\
\hline $\begin{array}{l}\text { Efikasi diri } \\
\text { *motivasi belajar }\end{array}$ & 2,059 & 0,089 & & & Linear \\
\hline
\end{tabular}

Sumber: SPSS 16.00 tahun 2021
Hasil uji linearitas menunjukkan hubungan antara variabel bebas dan variabel terikat bersifat linear. Hal itu ditunjukkan oleh harga $\mathrm{p}>0,05$ dimana antara variabel interaksi teman sebaya dengan motivasi belajar menghasilkan nilai F sebesar 1.783 ( $\mathrm{p}>0,05)$. Hubungan antara variabel Efikasi Diri dengan motivasi belajar menghasilkan nilai $\mathrm{F}$ sebesar 2,059 dengan ( $p>0,05)$.

\section{HASIL DAN PEMBAHASAN}

Analisis data untuk menguji hubungan antara interaksi teman sebaya dan efikasi diri dengan motivasi belajar menggunakan analisis regresi ganda dua predictor dan hasil analisis menunjukkan koefisien regresi $(\mathrm{R})=0,354$ koefisien determinasi $\left(\mathrm{R}^{2}\right)$ sebesar 0,125 artinya secara simultan interaksi teman sebaya dan efikasi diri memberikan sumbangan efektif sebesar $12,5 \%$ terhadap motivasi belajar sehingga masih ada $87.5 \%$ variabel lain yang mungkin dapat menjelaskan factorfaktor lain yang mempengaruhi motivasi belajar. berdasarkan uraian di atas dapat disimpulkan bahwa interaksi teman sebaya dan efikasi diri merupakan salah satu factor yang mendukung motivasi belajar.

Hasil penelitian ini mendukung hasil penelitian yang dilakukan oleh Syafi'I (2018) menunjukkan ada hubungan yang signifikan antara interaksi teman sebaya terhadap motivasi belajar. 
Anggun (2021) menjelaskan hal yang sama bahwa terdapat pengaruh interaksi sosial teman sebaya terhadap motivasi belajar siswa kelas VIII SMP Negeri 15 Semarang.

Berdasarkan uraian di atas dapat disimpulkan bahwa interaksi teman sebaya merupakan salah satu faktor yang mendukung motivasi belajar. Monica (2017) mengatakan efikasi diri dan motivasi belajar siswa memiliki pengaruh positif dan signifikan terhadap hasil belajar, baik secara parsial maupun simultan oleh karena itu hasil belajar dapat ditingkatkan melalui peningkatan efikasi diri dan motivasi belajar. hal ini berarti interaksi teman sebaya dan efikasi diri secara bersama-sama mempunyai hubungan dengan motivasi belajar.

\section{PENUTUP}

\section{Kesimpulan}

Berdasarkan hasil penelitian tentang hubungan antara interaksi teman sebaya dan efikasi diri dengan motivasi belajar dapat disimpulkan sebagai berikut:

1. Ada hubungan positif antara interaksi teman sebaya dan efikasi diri dengan motivasi belajar; 2. Interaksi teman sebaya dan efikasi diri berpengaruh pada motivasi belajar sebesar $12,5 \%$. sehingga masih ada factor lain yang lebih mempengaruhi motivasi belajar seperti faktor internal dan eksternal sebanyak $87,5 \%$

\section{Saran}

\section{Bagi Guru}

Hasil Penelitian ini dapat digunakan sebagai bahan masukan oleh guru untuk memperbaiki interaksi teman sebaya dan efikasi diri siswa agar siswa lebih termotivasi dalam belajar.

\section{Bagi Siswa}

Hasil penelitian ini dapat digunakan sebagai bahan masukan kepada siswa untuk menambah pengetahuan para siswa mengenai interaksi teman sebaya. mempengaruhi motivasi belajar siswa selain itu efikasi diri pada diri siswa juga sangat penting untuk dipahami oleh siswa karena efikasi diri juga mempengaruhi motivasi belajar siswa.

\section{Peneliti Selanjutnya}

Hasil penelitian ini menunjukkan bahwa variable interaksi teman sebaya dan efikasi diri ternyata mempengaruhi motivasi belajar siswa hanya $12,5 \%$. Hasil penelitian ini bisa saja berubah dikarenakan saat peneliti melakukan penelitian ini pada saat kondisi pandemic covid 19. Sehingga para peneliti selanjutnya dapat melakukan penelitian kembali secara lebih mendalam mengenai interaksi teman sebaya, efikasi diri dan motivasi belajar 


\section{DAFTAR PUSTAKA}

Anggun, P.D \& Yovitha, Y, D.M. 2021. Interaksi Sosial Teman Sebaya Terhadap Motivasi Belajar Siswa. Jurnal Penelitian dan Pengembangan Pendidikan. Vol.5 No. 163-167

Bandura, A. 1997. Self-Efficacy Toward A Unfying Theory of Behavioral Psychology. Review.

Departemen Pendidikan dan Kebudayaan. 2005. Kamus Besar Bahasa Indonesia. Jakarta: Balai Pustaka

Djamarah, S.B. 2015. Psikologi Belajar. Jakarta: Rineka Cipta

Ellis, O.J. 2008. Psikologi Pendidikan: Membantu siswa Tumbuh dan Berkembang. Jakarta: Erlangga.

Heni, I. W. 2018. Pengaruh Efikasi Diri, Motivasi Belajar dan Lingkungan Sekolah Terhadap Prestasi Belajar Siswa Pada Mata Pelajaran Ekonomi Kelas X dan XI IIS di SMA Negeri 6 Yogyakarta. Skripsi (diterbitkan). Yogyakarta: Fakultas Keguruan dan Ilmu Pendidikan: Universitas Sanata Dharma.
Monica \& Adman. 2017. Peran Efikasi Diri dan Motivasi Belajar Dalam Meningkatkan Hasil Belajar Siswa Sekolah Menengah Kejuruan. Vol 2 No.2 hal 219226.

Ngalim. 2013. Psikologi Pendidikan. Bandung: Remaja Rosdakarya

Priyatno. 2018. SPSS Panduan Mudah Olah Data bagi Mahasiswa dan Umum. Yogyakarta: Andi.

Sardiman. 2007. Interaksi dan Motivasi Belajar-Mengajar. Jakarta : PT Raja Grafindo Persada.

Sardiman. 2018. Interaksi dan Motivasi Belajar-Mengajar. Jakarta : PT Raja Grafindo Persada.

Syafi'I, M \& Ummi, M. 2018. Pengaruh Interaksi Teman Sebaya Terhadap Motivasi Belajar santri. Jurnal Pendidikan Islam. Vol 2 No.1

Santrock, W. J. 2003. Adolescence: Perkembangan Remaja. Erlangga: Jakarta

Winkel, WS. 2014. Psikologi Pengajaran. Yogyakarta: Media Abadi. 